\title{
Application of Biological Pretreatment using Enzyme Extracts from Filamentous Fungi to Improve Ruminal Degradability of Oil Palm Fronds.
}

Mohammad Azri Azmi

Universiti Putra Malaysia https://orcid.org/0000-0002-5956-1908

Mohd. Termizi Yusof

Universiti Putra Malaysia

Zunita Zakaria

Universiti Putra Malaysia

Noordin Mohamed Mustapha

Universiti Putra Malaysia

Mohd Zamri Saad

Universiti Putra Malaysia

Hasliza Abu Hassim ( $\sim$ haslizaabu@upm.edu.my )

https://orcid.org/0000-0002-7119-6560

\section{Research}

Keywords: palm oil, Malaysia, enzyme extract, white rot fungi

Posted Date: June 4th, 2020

DOI: https://doi.org/10.21203/rs.3.rs-31049/v1

License: () (1) This work is licensed under a Creative Commons Attribution 4.0 International License.

Read Full License 


\section{Abstract \\ Background}

Malaysia is one of the largest producer of palm oil in the world with yearly yield of 19000 million tonnes. With its large scale production of palm oil, Malaysia produces approximately 30 million tonnes of oil palm fronds (OPF) annually. The OPF as the main agricultural by-product in Malaysia have limited use especially as ruminant feed. It is due to its poor degradability which is caused by its high lignin content. One of the most promising method to increase the utilization of OPF as ruminant feed is via biological pretreatment. Previous study has shown an increase of $12 \%$ of ruminal degradability when pretreated using enzyme extract from white rot fungi

\section{Results}

The isolation of fungi yielded 11 fungi isolates. Upon the determination of their laccase, manganese peroxidase, lignin peroxidase, carboxylmethylcellulase, avicelase and xylanase, fungi F1, F2 and F4 were selected as the fungi with desirable enzyme activity. The fungi F1, F2 and F4 were then identified as Trichoderma harzianum MK027304, Trichoderma harzianum MK027305 and Fusarium solani MK027307 respectively. The highest total gas production was produced by OPF pretreated with enzyme extract from 15 days of solid state fermentation of Trichoderma harzianum MK027304. The highest methane was produced by OPF pretreated with enzyme extract from 30 days of solid state fermentation of Trichoderma harzianum MK027305. Highest volatile acid produced by OPF pretreated with enzyme extract from Fusarium solani MK027307 after 45 days of solid state fermentation. The apparent rumen degradable carbohydrate of the pretreatment also showed the highest increase over the unpretreated OPF with increment of $35.29 \%$.

\section{Conclusions}

The pretreatment using enzyme extract from 45 days of solid state fermentation of Fusarium solani MK027307 have shown the ability to increase the degradability of OPF by $35.29 \%$. This finding may decrease the feeding cost of ruminant by increasing the effectiveness of utilization of OPF.

\section{Introduction}

Malaysia is known to be one of the most prominent palm oil producer in the world. The production of Malaysia's palm oil is second only to Indonesia (Pakiam, 2013). Malaysia harbors 5.64 million hectares of oil palm plantation throughout the nation and boasted an average 19000 million tonnes of annual palm oil production which contributed $32 \%$ of global fats and oils production. (Mahlia, 2015). 
The large scale nature of oil palm plantation in Malaysia resulted in large amount of agricultural byproduct product being produced. The main by-product from oil palm plantation in Malaysia is oil palm fronds (OPF). The OPF constitute approximately $2 / 3$ of total agricultural by-product produced from oil palm plantation. Annually, Malaysia produced 30 million tonnes of OPF (Wan Zahari and Farid, 2011).

Ruminant industry in Malaysia is still struggling to meet the local demands. The self-sufficiency level of beef, mutton and milk for the year 2014 were rated at $29.84 \%, 13.10 \%$ and $12.93 \%$ respectively. This low volume of production is driven by lack of land resources, poor involvement from private sector, cheaper substitute and high feeding cost (Shanmugavelu, 2014).

As previously mentioned, high feeding cost is one of the contributing factors in limiting the selfsufficiency level of ruminant. Indeed, feeding cost constitute a large portion of livestock production cost. It is reported that feeding cost make up 60 to $70 \%$ of the production cost (Loh, 2002).

Agricultural by product were commonly used as animal feed in Malaysia. This is especially true in the ruminant industry in which locally available feedstuff were used alongside imported ingredients. The OPF, being one of the most abundant agricultural by-products in Malaysia is commonly included in the ruminant feed (Loh, 2002). However, OPF have limited effectiveness in its utilization due to its high lignin content. The lignin content along with the cellulose and hemicellulose make up the lignocellulosic biomass (Zhang and Zhao, 2010). The biomass plays an important role in imparting strength to the plant and prevents enzymatic degradation. Further, the lignin content in the biomass have the ability to remove the enzymes from the reaction site via adsorption process. Nevertheless, this biomass could also prevents the effective utilization of OPF by limiting the access of rumen microbes to the fermentable cellulose and hemicellulose (Binod et al., 2012).

Various methods have been implemented to increase the ruminal degradability of OPF. However, only biological pretreatment methods have shown promising result. Apart from that, other method such as physical, physicochemical and chemical pretreatment have been shown to produce undesirable chemical residue which may hamper subsequent process and requires expensive setup (Laser et al., 2002; Rabelo et al., 2009). Indeed, a study by Hassim et al., 2012 shows an increase of $12 \%$ of ruminal degradability when OPF underwent pretreatment from enzyme extracts from white rot fungi.

In this study, filamentous fungi from OPF were isolated and their enzymes were analyzed. Then, the fungi which produce the desirable enzymes profile were selected and their species were identified. The enzyme extracts were then used to pretreat the OPF and the ruminal degradability of the pretreated OPF were examined in in vitro study.

\section{Materials And Methods}

Isolation and Cultivation of Filamentous Fungi 
Fungi samples were collected from OPF in Taman Pertanian Universiti, Universiti Putra Malaysia. Fungi growth on the OPF were scrapped off into sample bags and was taken to FAMTEC lab. The fungi were then repeatedly subcultured onto potato dextrose agar and incubated at $30^{\circ} \mathrm{C}$ for $72 \mathrm{~h}$ until a pure culture were obtained (Namoolmoy et al., 2011).

\section{Enzyme Extraction of Filamentous Fungi}

The enzymes were extracted using solid state fermentation technique in which the OPF were used as substrate. TheOPF were collected from Taman Pertanian Universiti, Universiti Putra Malaysia. The OPF were then chopped into smaller pieces using an industrial chopper. The chopped OPF were then further grounded using Waring Laboratory 7010BU blender to smaller pieces sized $0.5 \mathrm{~mm}$. The enzymes extraction were done in triplicates for each fungi isolated. A total of $15 \mathrm{~g}$ of OPF were placed inside 250 $\mathrm{ml}$ Erlenmeyer flask for each replicate. Apart from the OPF, each Erlenmeyer flask received $45 \mathrm{ml}$ distilled water, $22.5 \mathrm{mg}$ glucose and $1.2 \mathrm{mM}$ ammonium sulphate. The flasks were then autoclaved at $121^{\circ} \mathrm{C}$ for 15 minutes to remove any existing microorganism present in the flasks. Afterwards, each flask received 3 agar plugs from the fungi culture measuring $10 \mathrm{~mm}$ each. The flasks were then sealed with cotton ball and aluminum foil. The fermentation periods were set at 15,30 and 45 days at $30^{\circ} \mathrm{C}$. Once the fermentation period completed, the enzymes were extracted. For extraction, each flask received $150 \mathrm{ml}$ distilled water and was shaken on rotary shaker for 3 hours. The content of each flask were then filtered through 5 layers of wound gauze. The filtrands were then added with polyvinyl polypyralidone (PVPP). 6 $\mathrm{g}$ of PVPP was used for $30 \mathrm{ml}$ of filtrands. The mixtures were then centrifuged at $12,000 \mathrm{~g}$ at $4{ }^{\circ} \mathrm{C}$. The supernatants were then collected for enzyme activity determination ( $5 \mathrm{ml}$ in $15 \mathrm{ml}$ tube) and pretreatment with OPF (20 $\mathrm{ml}$ in $50 \mathrm{ml}$ tube).

\section{Determination of Enzymes Activity}

\section{Lignolytic Enzymes}

For Laccase (EC 1.10.3.2) activity determination, citrate-phosphate buffer was prepared by adding 1.921 $\mathrm{g}$ citric acid to $100 \mathrm{~mL}$ of distilled water. The solution was labelled as solution $\mathrm{A}$. Then, $3.581 \mathrm{~g}$ of sodium phosphate dibasic, $\mathrm{Na}_{2} \mathrm{HPO}_{4}$ was added into $100 \mathrm{~mL}$ of distilled water. The solution was then labelled as solution $\mathrm{B}$. Equal amount of solution $\mathrm{A}$ and $\mathrm{B}$ was mixed and the $\mathrm{pH}$ is adjusted to $\mathrm{pH}$ 4.0. For the substrate, ABTS solution was prepared by adding $0.165 \mathrm{~g}$ of 2,2'-azino-bis(3-ethylbenzothiazoline-6sulphonic acid), ABTS to $10 \mathrm{~mL}$ of distilled water. The ABTS solution was then transferred to an Eppendorf tube. The mixture tube was prepared by adding $1300 \mu$ l citrate-phosphate buffer, $100 \mu$ ABTS and $100 \mu$ l enzyme extract. For the blank, $1300 \mu$ l citrate-phosphate buffer was mixed with $100 \mu$ ABTS. The mixtures were then covered with parafilm and were read at absorbance of $420 \mathrm{~nm}$ against blank (Dinis et al. 2009).

Lignin Peroxidase (EC 1.11.1.14; LiP) was determined by preparing acid tartrate buffer. Acid tartrate weighing $3.752 \mathrm{~g}$ was added in $250 \mathrm{~mL}$ distilled water. The $\mathrm{pH}$ was then adjusted to 3.0 by using acid/sodium tartrate buffer. The buffer was then kept in $4^{\circ} \mathrm{C}$. The substrate was prepared by adding 
$0.105 \mathrm{~mL}$ veratryl alcohol with $25 \mathrm{~mL}$ distilled water. The solution was then store at $4{ }^{\circ} \mathrm{C}$ in Eppendorf tubes. Hydrogen peroxide, $\mathrm{H}_{2} \mathrm{O}_{2}$ was then prepared according to manufacturer specification. The mixture tube was prepared by adding $2550 \mu \mathrm{l}$ of acid tartrate buffer, $200 \mu \mathrm{l}$ veratryl alcohol, $30 \mu \mathrm{l} \mathrm{H}_{2} \mathrm{O}_{2}$, and $200 \mu \mathrm{l}$ enzyme extract. For the blank, the mixture solution was prepared with $2550 \mu \mathrm{l}$ acid tartrate buffer, $200 \mu \mathrm{l}$ veratryl alcohol and $30 \mu \mathrm{l} \mathrm{H}_{2} \mathrm{O}_{2}$. The tubes were read at absorbance of $238 \mathrm{~nm}$ against blank (Dinis et al, 2009).

For screening of Manganese Peroxidase (EC 1.11.1.13; MnP) activity, tartrate buffer was prepared by adding $5.752 \mathrm{~g}$ sodium tartrate with $250 \mathrm{~mL}$ distilled water. The $\mathrm{pH}$ was adjusted to 5.0 by adding either acid or sodium tartrate buffer. The solution was then kept at $4^{\circ} \mathrm{C}$. For the substrate preparation, $0.254 \mathrm{~g}$ of Manganese sulphate, $\mathrm{MnSO}_{4}$ was mixed with $50 \mathrm{~mL}$ of distilled water. It was then stored in $4{ }^{\circ} \mathrm{C} . \mathrm{H}_{2} \mathrm{O}_{2}$ was prepared according to manufacturer's standard. The mixture tube was prepared by adding $2550 \mu \mathrm{l}$ sodium tartrate buffer, $200 \mu \mathrm{l}$ manganese sulphate, $30 \mu \mathrm{H}_{2} \mathrm{O}_{2}$, and $200 \mu \mathrm{l}$ enzyme extract. For the blank, the mixture consists of $2550 \mu \mathrm{l}$ sodium tartrate buffer, $200 \mu \mathrm{l}$ manganese sulphate, and $30 \mu \mathrm{l} \mathrm{H}_{2} \mathrm{O}_{2}$. The absorbance was then read at 238nm (Dinis et al, 2009).

\section{Cellulolytic Enzymes}

For the purpose of screening Carboxylmethylcellulase (CMcase) enzyme activity, the substrate was prepared by adding $1 \mathrm{~g}$ of carboxymethylcellulose to $100 \mathrm{~mL}$ distilled water in $250 \mathrm{~mL}$ Erlenmeyer flask. The solution was then stirred until it became homogeneous. The buffer used in this experiment is $0.1 \mathrm{M}$ citrate buffer set at $\mathrm{pH}$ 4.8. The reaction mixture is prepared by adding $1 \mathrm{~mL}$ of citrate buffer, $0.5 \mathrm{~mL}$ enzyme extract, and $0.5 \mathrm{~mL}$ carboxymethyl cellulose. The substrate control tube was prepared by adding $1.5 \mathrm{~mL}$ of citrate buffer and $0.5 \mathrm{~mL}$ carboxymethylcellulose. The enzyme control tubes were prepared by adding $1.5 \mathrm{~mL}$ of citrate buffer and $0.5 \mathrm{~mL}$ of enzyme extract. The tubes were then incubated at $39^{\circ} \mathrm{C}$ for 20 minutes. The reaction was stopped by adding $3 \mathrm{~mL}$ of dinitrosalicylic acid, DNS to each tube. The reaction, the enzyme control, and the substrate control tubes were placed in boiling water bath for 10 minutes and were then read at absorbance of $575 \mathrm{~nm}$. Calibration curve was made by plotting absorbance against glucose concentration. The glucose solution was prepared by dissolving $0.1 \mathrm{~g}$ of glucose in $100 \mathrm{~mL}$ of distilled water (Dinis et al, 2009).

In this experiment to determine avicelase enzyme activity, the buffer used was $0.1 \mathrm{M}$ citrate buffer set at $\mathrm{pH}$ 4.8. The substrate was prepared by dissolving $1 \mathrm{~g}$ of Avicel microcrystalline in $100 \mathrm{~mL}$ of distilled water in $250 \mathrm{~mL}$ Erlenmeyer flask. The solution was then stirred until it became homogeneous. The reaction mixture was prepared by adding $1 \mathrm{~mL}$ citrate buffer, $0.5 \mathrm{~mL}$ of enzyme extract and $0.5 \mathrm{~mL}$ Avicel cellulose microcrystalline. Substrate control tube was prepared by adding $0.5 \mathrm{~mL}$ substrate with $1.5 \mathrm{~mL}$ citrate buffer. The enzyme control tube was prepared by mixing $0.5 \mathrm{~mL}$ enzyme extract with $1.5 \mathrm{~mL}$ citrate buffer. The tubes were then incubated at $39^{\circ} \mathrm{C}$ for 20 minutes. The reaction was stopped by adding $3 \mathrm{~mL}$ DNS solution to each test tube. The reaction and control tubes were then placed inside boiling water bath for 10 minutes. The absorbance was read at $575 \mathrm{~nm}$ against blank. Standard calibration curve was 
plotted against glucose concentration. The $0.1 \%$ glucose standard was prepared by dissolving $0.1 \mathrm{~g}$ glucose in $100 \mathrm{~mL}$ distilled water (Dinis et al, 2009).

\section{Hemicellulolytic Enzyme}

For xylanase enzyme activity screening, the substrate, xylan, was prepared by adding $0.25 \mathrm{~g}$ of xylan to $100 \mathrm{~mL}$ of distilled water. The mixture was then heated to $70^{\circ} \mathrm{C}$ with continuous shaking. The assay mixture was prepared by adding $1.5 \mathrm{~mL}$ of $0.1 \mathrm{M}$ citrate buffer set at $\mathrm{pH} 4.8,0.5 \mathrm{~mL}$ enzyme extract and $0.5 \mathrm{~mL}$ of $0.25 \%$ xylan. The control tube for substrate control was prepared by adding $0.5 \mathrm{~mL} 0.25 \%$ xylan with $1.5 \mathrm{~mL}$ citrate buffer. For the enzyme control tubes, $0.5 \mathrm{~mL}$ of sample was mixed with $1.5 \mathrm{~mL}$ phosphate buffer. The tubes were incubated at $39^{\circ} \mathrm{C}$ for 30 minutes. The reaction was stopped by adding $3 \mathrm{~mL}$ of DNS to each reaction tube. All tubes were placed in boiling water bath for 10 minutes and absorbance was read at $575 \mathrm{~nm}$ against blank. Calibration curve was prepared by plotting absorbance against xylose concentration. The standard xylose solution was prepared by dissolving $0.1 \mathrm{~g}$ of xylose in $100 \mathrm{~mL}$ of distilled water (Dinis et al, 2009).

\section{Selection of Fungi Isolate with Optimum Enzyme Activity}

The result yielded from determination of enzymes activity of isolated fungi was used. The best fungi were chosen using scatterplot method with the $y$-axis representing average of total lignolytic activity and $x$-axis represents cellulolytic + hemicellulolytic average enzyme activity. Both axis represents their value in $\mathrm{U} / \mathrm{mL}$.

\section{Identification of Selected Fungi Species}

\section{Morphological Identification}

Macroscopic observation for morphological identification purpose was done by culturing the selected fungi on PDA agar for 7 days. Their morphology on the agar plate were then observed (Kusai et al., 2018). The criteria observed are the texture, the structure, the edge of the culture and the elevation of the culture.

Microscopic observation for morphological identification purpose was done by placing the fungi onto a glass slide. The fungi were then covered with cover slip and pressed to obtain a good separation of the hyphae. The fungi were then stained using methylene blue solution. Their conidia were then identified using method by Kusai et al., 2018.

\section{Molecular Identification}

The DNA was extracted from the fungi isolates using QIAGEN DNeasy plant kit according to manufacturer's manual. The ITS region of the DNA extracts were amplified using ITS1 (5'TCCGTAGGTGAACCTGCGG-3') as forward primer and ITS4 (5'-TCCTCCGCTTATTGATATGC-3') as reverse primer in polymerase chain reaction (PCR). . The PCR products were then sent to a service provider to be sequenced. The sequences were then assembled and aligned using Biology Workbench 3.2 
(http://workbench.sdsc.edu). The assembled sequenced were then compared with sequence in GenBank using Basic Local Alignment Search Tool (BLAST) (http://www.ncbi.nlm.gov). Maximum likelihood phylogenic tree was constructed using MUSCLE alignment and Gblocks alignment curation (Dereeper et al., 2010).

\section{Pretreatment of OPF with Enzyme Extract}

The enzyme extracted from 15, 30 and 45 days of solid state fermentation of the selected fungi were used. Pretreatment was done in triplicate. Each flask received $20 \mathrm{ml}$ of enzyme extracts. Citrate buffer was prepared by combining $10.507 \mathrm{~g}$ of citric acid in 1 litre of water with $14.705 \mathrm{~g}$ of sodium citrate in 1 litre of water. The solutions were then mixed and the $\mathrm{pH}$ was adjusted to 5.0. The solution measuring 70 $\mathrm{mL}$ was added to $250 \mathrm{~mL}$ erlenmeyer flask containing $11 \mathrm{~g}$ of OPF. Then, manganese sulphate solution measuring $6.7 \mathrm{~mL}$ was added to the flasks. Manganese sulphate solution was prepared by dissolving $0.0634 \mathrm{~g}$ of manganese sulphate powder in $250 \mathrm{~mL}$ of distilled water. Hydrogen peroxide measuring 1 $\mathrm{mL}$ was also added to each flask. The flasks were then covered with cotton ball and aluminium foil. The flasks were then incubated for 6 days at $40^{\circ} \mathrm{C}$. Once the incubation ended, the content was filtered through wound gauze and the filtrands were collected and dried at $60^{\circ} \mathrm{C}$, the dried pretreated OPF were then stored for future use (Rodriguez et al., 2008).

\section{Rumen Fluid Collection}

Rumen fluid was collected from non-adapted fistulated Brahman bull in Ladang 15, Faculty of Agriculture, Universiti Putra Malaysia. The rumen fluid was then carried in prewarmed thermos flask which was previously flushed with $\mathrm{CO}_{2}$. The rumen fluid was then filtered through 4 layers of wound gauze and kept warm at $39^{\circ} \mathrm{C}$ with constant flow of $\mathrm{CO}_{2}$. The pH of the rumen fluid was then recorded using Mettler Toledo FE20-ATC pH meter (Rodriguez et al., 2008).

\section{Buffers Preparation}

Phosphate buffer was prepared by dissolving $28.8 \mathrm{~g}$ of sodium phosphate dibasic dodecahydrate, $\mathrm{Na} 2 \mathrm{HPO} 4 \cdot 12 \mathrm{H} 2 \mathrm{O}, 6.1 \mathrm{~g}$ of sodium phosphate monobasic dihydrate, $\mathrm{NaH} 2 \mathrm{PO} 4 \cdot \mathrm{H} 2 \mathrm{O}$ and $1.4 \mathrm{~g}$ of Ammonium chloride, $\mathrm{NH} 4 \mathrm{Cl}$ in 1 litre of distilled water. The solution was then adjusted to $\mathrm{pH}$ 6.8. The solution was then flushed with $\mathrm{CO}_{2}$ for 1.5 hour (Rodriguez et al., 2008).

Bicarbonate buffer was prepared by dissolving 39. $2 \mathrm{~g}$ of sodium bicarbonate, $\mathrm{NaHCO} 3$ in 1 litre of distilled water. The solution was then flushed with $\mathrm{CO}_{2}$ for 1.5 hour (Rodriguez et al., 2008).

\section{In Vitro Fermentation}

The in vitro incubation was carried out in $100 \mathrm{~mL}$ syringe. Each test syringe receives $0.175 \mathrm{~g}$ concentrate, $0.075 \mathrm{~g}$ pretreated OPF, $5 \mathrm{~mL}$ rumen fluid, $10 \mathrm{~mL}$ phosphate buffer and $10 \mathrm{~mL}$ bicarbonate buffer. The control syringe for OPF only receives $0.25 \mathrm{~g}$ of unpretreated OPF, $5 \mathrm{~mL}$ rumen fluid, $10 \mathrm{~mL}$ phosphate buffer and $10 \mathrm{~mL}$ bicarbonate buffer. The control syringe for concentrate only receives $0.25 \mathrm{~g}$ of 
concentrate, $5 \mathrm{~mL}$ rumen fluid, $10 \mathrm{~mL}$ phosphate buffer and $10 \mathrm{~mL}$ bicarbonate buffer. Another control set of syringes was prepared which contain $0.175 \mathrm{~g}$ concentrate, $0.075 \mathrm{~g}$ unpretreated OPF, $5 \mathrm{~mL}$ rumen fluid, $10 \mathrm{~mL}$ phosphate buffer and $10 \mathrm{~mL}$ bicarbonate buffer. The incubation was carried out for 72 hours. The gas production at the $2,4,6,8,10,12,20,28,36,44,52,60,68$, and 72 -hour interval was recorded (Rodriguez et al., 2008).

\section{Total Gas and Methane Gas Determination}

After $72 \mathrm{~h}$, the value of the total gas produced is measured. Then, $5 \mathrm{~mL}$ sodium hydroxide was added to the syringes allocated for methane production determination. The added sodium hydroxide raises the $\mathrm{pH}$ of the syringe content and stop the fermentation process. The carbon dioxide content was then absorbed by the sodium hydroxide solution. The measurement of the syringe was taken 1 hour after the addition of sodium hydroxide solution (Rodriguez et al., 2008).

\section{Volatile Fatty Acid Determination}

After $72 \mathrm{~h}$, the content for syringes allocated for volatile fatty acid determination was extracted and added with $2 \mathrm{~mL}$ of $25 \%$ metaphosphoric acid to stop the incubation process. The solution was then centrifuged at $1500 \mathrm{rpm}$ for 10 minutes. A total of $0.5 \mathrm{~mL}$ of the supernatant was then placed inside $\mathrm{GC}$ vial containing $0.5 \mathrm{~mL} 1 \mathrm{~mol}$ methyl-n-valeric acid.

The determination of the volatile fatty acid was carried out using gas chromatography method. The machine used is Agilent 222-3232L with DB-FFAP (G3900-63025) column. The flowrate is $1 \mathrm{~mL} / \mathrm{min}$ with pressure of $13.51 \mathrm{psi}$ and average velocity of $27 \mathrm{~cm} / \mathrm{sec}$. The mobile phase used is helium with split ratio of $30: 1$.

The apparent rumen degradable carbohydrate was measured using the formula:

$\operatorname{ARDC}(\mathrm{mg})=($ Acetate $/ 2+$ Propionate/2+Butyrate $) \times 162 / 1000$,

The value 162 is the assumed molecular weight of $1 \mathrm{~mol}$ of fermented carbohydrate (Demeyer, 1991). The acetate, propionate and butyrate were expressed as net micro molar production.

\section{Results}

\section{Isolation of Fungi}

From the isolation process, 11 distinct fungi were harvested. The fungi were labelled as F1 to F11.

\section{Determination of Enzyme Activities}

The lignolytic enzymes activity shows the highest reading in all the fungi. All the fungi tested showed highest lignolytic activity at day 45 with exception of $\mathrm{F} 3$ as represented in Figure 1. For the lignin peroxidase, F2 and F6 showed highest activity on day 15 while F1, F4 and F7 record highest activity on 
day 30. F3, F5, F8, F9, F10 and F11 recorded highest lignin peroxidase activity on day 45. In Manganese Peroxidase activity determination, F2, F4, F5, F7, and F9 recorded the highest activity on day 15. Fungi F1, F6 and F 11 recorded the highest Manganese Peroxidase on day 30 . The rest of the fungi have the highest manganese peroxidase activity recorded on day 45.

In cellulolytic enzyme activity determination, the activity of avicelase recorded highest reading on day 15 followed by day 30 and 45 respectively across all fungi tested. The carboxymethylcellulase activity showed that F5, F8, F9, and F11 had the highest reading across all the fungi tested for all the time period tested as shown in Figure 2.

All the fungi show low hemicellulolytic enzyme activity with the exception of F5, F8, F9 and F11 as shown in Figure 3. The enzyme activity for the enzyme tested, xylanase showed consistent reading for 15, 30 and 45 days, the activity of the enzyme showed highest reading on day 30.

\section{Fungi Selection Based on Enzyme Activities}

The selection of optimal fungi for pretreatment process was carried out by constructing a scatterplot of average lignolytic enzymes activity against average of total cellulolytic activity and hemicellulolytic activity (Figure 4). From the scatterplot, it was found that F1, F2 and F4 (circled) exhibit the desired traits. These fungi occupy the top left hand corner of the scatterplot which indicates that the fungi have the highest lignolytic enzyme activity and low cellulase and hemicellulase activity.

\section{Morphological Observation of Selected Fungi}

The cultured fungi F1 forms filamentous structure on the PDA agar. The colony formed concentric rings with green coloration. The aerial mycelium of the fungi is abundant and forms cottony structure on the PDA agar. Apart from that, the elevation shown raised morphology. The margin of the cultured fungi showed filiform shape (Figure 5a).

For the microscopic observation of the fungi F1, the conidia showed pyramidal shape with opposing branches. The branches are widely spaced and end with 2-5 phialides. The conidia were ovoid shaped. Each conidiophore is approximately $10 \mu \mathrm{m}$ in length (Figure 5b).

Fungi F2 formed filamentous structure on the PDA agar with green concentric rings. Apart from that, there are abundance of aerial mycelium with cottony texture. The culture also exhibited raised elevation with filiform edges (Figure 6a).

For the microscopic observation of the fungi F2. The conidia are ovoid in shaped. The branches are widely spaced with 2 to 5 phialades at the end. The conidiophores is approximately $10 \mu \mathrm{m}$ in length (Figure 6b).

Fungi isolate F4 showed abundance of aerial mycelia with white cottony texture. The fungi form filamentous structure of the PDA agar. The edges of the culture exhibited filiform morphology with raised 
elevation (Figure 7a).

Upon performing the microscopic observation of the fungi, the conidia are present in the form of chlamydiaspore. The chlamydospore were formed in singular ovoid form with smooth wall. The size of chlamydospore is approximately $5 \mu \mathrm{m}$ in diameter Figure $7 \mathrm{~b}$ ).

\section{Total Gas and Methane Production}

The gas production after $72 \mathrm{~h}$ of in vitro fermentation showed the highest gas production among the experimental syringe was exhibited by syringe containing OPF pretreated with Trichoderma harzianum MK027304 Enzyme extract after 15 days of fermentation with $13.5 \mathrm{~mL}$ of gas produced which indicated a $21.97 \%$ increase over the non-pretreated OPF as shown in figure 10. The difference is significant at $\mathrm{p}<0.05$.

In Figure 11, the syringe containing OPF pretreated using enzyme extract from Trichoderma harzianum MK027305 after 30 days of solid state fermentation showed the highest methane gas production among all experimental syringes at $8.25 \mathrm{~mL}$. The lowest methane gas among experimental syringes was produced in the syringe containing OPF pretreated with enzyme extract from Fusarium solani MK027307 after 45 days of solid state fermentation. Among the control group, the syringe containing concentrate shows the highest methane gas production at $9.5 \mathrm{~mL}$. The blank syringe containing the rumen fluid showed minimal methane gas production at $0.5 \mathrm{~mL}$.

\section{Volatile Fatty Acid Production}

The experimental syringes that showed increase of total VFA production when compared with syringe containing normal diet are syringes containing OPF pretreated with enzyme extract from Trichoderma harzianum MK027304 after 30 and 45 days of solid state fermentation, Trichoderma harzianum MK027305 after 15 and 30 days of solid state fermentation and Fusarium solani MK027307 after 45 days of solid state fermentation. The syringe containing OPF pretreated with enzyme extract extracted from Fusarium solani MK027307 after 45 days of solid state fermentation exhibits the highest total VFA production. The syringe containing only rumen fluid (blank) shows the lowest volatile fatty acid production among all syringes (Figure 12).

From graph in figure 13, all syringes showed high acetic production in relative to other volatile fatty acid in the same syringe with the exception of syringe containing OPF pretreated with Fusarium solani MK027307 extracted from 45 days of solid state fermentation in which showed higher butyric acid compared to the other volatile fatty acids produced. In addition, based on the graph, syringe containing OPF pretreated with enzyme extract from 30 days of solid state fermentation of Trichoderma harzianum MK027305 showed the highest acetic acid production among all syringes. Syringe containing OPF pretreated with enzyme extract extracted from Trichoderma harzianum MK027305 after 30 days of solid state fermentation shows the highest propionic acid production among all syringes. 
From the graph in figure 14, the syringe containing OPF pretreated with enzyme extracted from Fusarium solani MK027307 after 45 days of solid state fermentation showed the highest ARDC value at 0.22 for $\mathrm{g} / \mathrm{g}$ of OPF. The lowest ARDC for $\mathrm{g} / \mathrm{g}$ OPF among experimental group was exhibited by syringe containing OPF pretreated with enzyme extracted from Trichoderma harzianum MK027304 after 15 days of solid state fermentation at 0.15 . With the exception of syringe containing OPF pretreated with enzyme extract from Fusarium solani after 45 days of solid state fermentation, all the experimental group recorded lower ARDC for $\mathrm{g} / \mathrm{g}$ of OPF when compared with control syringe containing only goat concentrate.

\section{Discussions}

The enzyme activity assay shows lignolytic activity recorded the highest activity compared to other enzymes. This is due to usage of solid state fermentation media consisting OPF, glucose and ammonium sulphate which is conducive for production of lignolytic enzyme compared to using OPF alone. This finding is highly similar to the one reported by Levin et al., 2008. Addition of energy source and nitrogen source boosted the production of lignolytic enzyme activity. A report by Revankar and Lele, 2006, stated that the production of enzymes by the microorganisms, in this case, the fungi, is boosted by the presence of low molecular weight compounds.

Despite showing fluctuating activity throughout the 15, 30 and 45 days of solid state fermentation, the lignin peroxidase activity of the fungi isolated exhibited the highest average activity compared to other enzymes. This is due to lack of supplementation of manganese (II) ion in the culture media. The lack of $\mathrm{Mn}$ (II) ion in the solid state media enables the lignin peroxidase to have unrepressed activity. Indeed, a study by Bonnmare and Jeffries, 1989 showed that in media with low concentration of Mn(II) stimulate the production of Lignin Peroxidase. At Mn(II) concentration lower than $1.6 \mathrm{ppm}$, the lignin peroxidase activity is enhanced. However, concentration of $8.0 \mathrm{ppm}$ showed to completely inhibit lignin peroxidase.

The laccase activity showed an increase of activity with longer fermentation time. The laccase production depends on the nitrogen and carbon source present in the culture media. In general, the laccase activity exhibited the lowest average activity among the lignolytic enzymes. This is partly due to usage of ammonium sulphate instead of ammonium nitrate which was reported to have better effect on laccase activity (Singh et al., 2013). Apart from that, laccase production is induced by the presence of phenolic or aromatic compound related to lignin and lignin derivatives such as ferulic acid, guaiacol and veratryl alcohol.

The manganese peroxidase activity in the experiment showed fluctuations for the 15, 30 and 45 days fermentation period. The average activity of manganese peroxidase is higher than laccase but lower than lignin peroxidase. This is partly due to absence of $\mathrm{Mn}$ (II) supplementation which has shown to stimulate manganese peroxidase activity. The manganese activity was shown to increase with increasing supplementation of $\mathrm{Mn}$ (II) until up to $40 \mathrm{ppm}$. A higher $\mathrm{Mn}$ (II) concentration was shown to have slight inhibitory effect (Bonnmare and Jeffries, 1989). The absence of $\mathrm{Mn}(\mathrm{II})$ causes the inactivation of $\mathrm{H}_{2} \mathrm{O}_{2}$ 
which prevents the manganese peroxidase to complete its catalytic cycle (Singh et al., 2013). Apart from that, the usage of ammonium sulphate instead of ammonium nitrate also have detrimental effect on manganese peroxidase as ammonium nitrate is more suitable for manganese peroxidase activity (Li et al., 2010).

The result shows some fungi exhibit multiple peaks of recorded lignolytic enzyme activities. the finding is identical to previous reports on lignolytic enzymes (Arora et al., 2002; Chang et al, 2012). The later peak is present partly because release of intracellular lignolytic enzyme from fungal autolysis to the medium (Arora et al., 2002).

The result shows that cellulolytic enzymes show higher reading at the start of the experiment and followed a decreasing trend later. This is due to the formation of aromatic water-soluble product from delignification process which suppress the activity of cellulolytic enzyme (Alam et al., 2005).

For the hemicellulolytic enzymes, the drop of activity in day 45 is due to the depletion of resources as the hemicellulose has been broken down by xylanase (Khan et al, 2002).

The general low holocellulase activity exhibited by the activity of xylanase, avicelase and carboxymethylcellulase can be attributed to the addition of glucose in the solid state media. Glucose, as the final product of the fermentation of cellulose and hemicellulose decreases the enzymes activity as the easily utilizable sugar suppress the enzymatic activities (Lynd and Zhang, 2002). Apart from that, the presence of glucose has shown to inhibit the expression of cellulose genes (Ahmed et al., 2005). Other research also indicates minimal cellulose production when the glucose was used as primary carbon source (Malik et al., 1986).

From the morphological observation of the fungi culture, the fungi F1, F2 and F4 which were selected based on their enzymes activity. The fungi F1, F2 and F4 were found to belong to the genus Trichoderma, Trichoderma and Fusarium respectively. Fungi F1 and F2 shows distinct green ring which is synonymous with the Trichoderma species. Apart from that, the morphology of the conidiophores also confirms the fungi to belong to the Trichoderma genus. In the F4 microscopic observation, chlamydiopore were observed instead of conidia. This can be attributed to depletion of resources on the culture media (Old and Schipper, 1973). Fusarium is known as one of the ascomycetes which could produce chlamydiospore. The observation was confirmed by the molecular identification of the fungi which identify fungi F1, F2 and F3 as Trichoderma harzianum MK027304, Trichoderma harzianum MK027305 and Fusarium solani MK027307 respectively. The molecular result was backed by strong bootstrap value at $99 \%$.

In gas production determination, the pretreatment using enzyme extract from Trichoderma harzianum MK027304 after 15 days of solid state fermentation showed the highest methane production. Conventionally, the increased of gas produced is associated with increase in dry matter and organic matter disappearance (Wulansih et al., 2018). 
The highest methane and lowest methane production was shown by Trichoderma harzianum MKT027305 and Fusarium solani MKT027307 respectively. The production of methane gas represents the loss of $2-12 \%$ of energy by the host animal (Moss et al., 2000).

The highest fatty acid production in total was exhibited by syringe containing OPF pretreated with enzyme extract extracted from Fusarium solani MK027307 after 45 days of solid state fermentation at $145.99 \mathrm{mmol} / \mathrm{mol}$ as shown in Fig. 12. The value represents $21.67 \%$ increase over the non-pretreated OPF in normal diet. A significant increase at $\mathrm{P}<0.05$. Consequently, in Fig. 13 , the syringe also showed higher propionic acid production compared with other syringes with the exception of syringe containing OPF pretreated with enzyme extracted from Trichoderma harzianum MK027305 after 30 days of solid state fermentation. Apart from that, the syringe also exhibited the highest production of butyrate compared to the other syringe. The butyrate and propionate are produced more abundantly when the cattle are fed with rapidly fermentable carbohydrate. Propionate is the end product of starch and sugar and supply most of the energy needed for live weight gain and for the lactose production by the mammary. Further, propionate is more energy efficient due to its fermentation produces less wasted carbon dioxide and methane (Morand-Fehr, 2005). The result correlates with the enzyme activity profile of fungi Fusarium solani MK027307 which showed higher cellulose and hemicellulose activity and lower lignolytic activity among the selected fungi. This is due to the end product of cellulase being simple sugar. Hence, increasing the availability of fermentable sugar for the rumen microbe (Ali et al., 2002). The low methane production of the syringe as exhibited by Fig. 11 can also be attributed to the increased production of propionic acid as the its production reduce the supply of hydrogen gas for methane production (Wulansih et al., 2018).

The ARDC for $\mathrm{g} / \mathrm{g}$ of OPF also exhibited similar finding as the fatty acid produced in which the syringe containing OPF pretreated with enzyme extract extracted from Fusarium solani MK027307 after 45 days of solid state fermentation in which, the syringe exhibited the highest ARDC value at $0.23 \mathrm{~g} / \mathrm{g}$ of OPF as shown in Fig. 14. It is $35.29 \%$ increase over the non-pretreated OPFin normal diet which is significant at $P$ $<0.05$. This is due to the higher cellulolytic enzyme activity which provide easily fermented sugar for the rumen microbes resulting in higher butyrate and propionate production (Khezri et al., 2009).

Despite showing high lignolytic activity, pretreatment using enzyme from Trichoderma harzianum MK027304 and MK027305 regardless of solid state fermentation period have failed to show increase in volatile fatty acid production compared to the pretreatment using enzyme extract from Fusarium solani MK027307. Similar finding also exhibited by Levin et al (2008) which show no direct correlation between lignolytic enzyme activity and ruminal degradability. Indeed, the increase of ruminal degradability might be attributed to enzymes in the extract in which the activity was not measured such as beta-glucosidase, feroloyl and acetyl esterase (Wong, 2005). Feroloyl have been shown to have the ability to hydrolyze lignin-hemicellulose bond, hence, increasing the exposure of structural carbohydrate to cellulolytic enzymes (Dinis et al., 2009). Besides, the synergism between enzyme may also cause no correlation between enzymes could be detected among individual enzyme activity and their effect on biodegradation of cell wall (Borneman et al., 1990). 


\section{Conclusion}

The pretreatment using enzyme extract extracted from Fusarium solani MK027307 after 45 days of solid state fermentation showed the highest total volatile fatty acid. The pretreatment also resulted in better ARDC as compared to other fungi's enzymatic pretreatment. Apart from that, the pretreatment also exhibited minimal energy loss to the host animal as exhibited by its lower gas and methane production. Indeed, the high lignolytic activity of the enzyme extracted from Trichoderma harzianum MK027304 and MK027305 did not correlates to higher volatile fatty acid production in volatile fatty acid determination. This is may be attributed to other factors such as enzymes that are not measured such as betaglucosidase, feroloyl esterase and acetyl esterase.

Indeed, pretreatment using enzyme extract from Fusarium solani MK027307 have shown to increase ruminal degradability of OPF by $35.29 \%$.

\section{Declarations}

\section{Acknowledgements}

The author would like to express his gratitude to Ministry of Higher Education of Malaysia for awarding the Fundamental Research Grant Scheme, (FRGS/1/2017/WAB01/UPM/02/18/5540032) of which enables this study to be conducted.

\section{Ethics approval and consent to participate}

Not applicable

\section{Consent for publication}

Not applicable

\section{Availability of data and material}

Not applicable

\section{Competing interest}

Not applicable

\section{Funding}

The funding was provided by Ministry of Higher Education, Malaysia under the Fundamental Research Grant Scheme (FRGS/1/2017/WAB01/UPM/02/18/5540032).

\section{Author's contributions}


Not applicable

\section{Acknowledgement}

Not applicable

\section{References}

Ahmed, S., Aslam, N., Latif, F., Rajoka, M. I., and Jamil, A. (2005). Molecular cloning of cellulase genes from Trichoderma harzianum. Frontiers in Natural Product Chemistry, 1(1), 73-75.

Alam, M. Z., Muhammad, N., and Mahmat, M. E. (2005). by Solid State Bioconversion. American Journal of Applied Science, 2(2): 569-572.

Ali, R. E., Mansfield, S.D. and Saddler, S. D. (2002). Cellulases: Agents for Fiber Modification or Bioconversion? The effect of substrate accessibility on cellulose enzymatic hydrolyzability, Progress in Biotechnology, Elsevier, 21: 21-36

Arora, D. S., Chander, M., and Gill, P. K. (2002). Involvement of lignin peroxidase, manganese peroxidase and laccase in degradation and selective ligninolysis of wheat straw. International Biodeterioration \& Biodegradation, 50(2): 115-120.

Binod, P., Satyanagalakshmi, K., Sindhu, R., Janu, K. U., Sukumaran, R. K., and Pandey, A. (2012). Short duration microwave assisted pretreatment enhances the enzymatic saccharification and fermentable sugar yield from sugarcane bagasse. Renewable Energy, 37(1): 109-116.

Bonnarme, P., \& Jeffries, T. W. (1990). Mn (II) regulation of lignin peroxidases and manganese-dependent peroxidases from lignin-degrading white rot fungi. Applied Environmental Microbiology, 56(1), $210-217$.

Borneman, W. S., Hartley, R. D., Morrison, W. H., Akin, D. E., and Ljungdahl, L. G. (1990). Feruloyl and pcoumaroyl esterase from anaerobic fungi in relation to plant cell wall degradation. Applied Microbiology, Biotech., 33: 345-351

Chang, A. J., Fan, J., and Wen, X. (2012). Screening of fungi capable of highly selective degradation of lignin in rice straw. International Biodeterioration \& Biodegradation, 72, 26-30.

Dereeper, A., Audic, S., Claverie, J. M., and Blanc, G. (2010) BLAST-EXPLORER helps you building datasets for phylogenetic analysis. BMC Evolution Biology. Jan 12; 10:8.

Dinis, M. J., Bezerra, R. M. F., Nunes, F., Dias, A. A., Guedes, C. V., Ferreira, L. M. M., and Rodrigues, M. A. M. (2009). Modification of wheat straw lignin by solid state fermentation with white-rot fungi. Bioresource Technology, 100: 4829-4835. 
Hassim, H. A., Lourenço, M., Goh, Y. M., Baars, J. J. P., and Fievez, V. (2012). Rumen degradation of oil palm fronds is improved through pre-digestion with white rot fungi but not through supplementation with yeast or enzymes. Canadian Journal of Animal Science, 92: 79-87.

Khan, I. A., Butt, W.A., Ali, S., and Qadeer, M. A., (2002). Effect of carbon and nitrogen sources on Xylanase production by mutant strain of Aspergillus niger GCBMX-45. J. Biology Science. 2(2): 143-144.

Khezri, A., Rezayazdi, K., Mesgaran, M. D., and Moradi-Sharbabk, M. (2009). Effect of different rumendegradable carbohydrates on rumen fermentation, nitrogen metabolism and actation performance of Holstein dairy cows. Asian-Australasian Journal of Animal Sciences, 22(5): 651-658.

Kusai, N. A., Ayob, Z., Maidin, M. S. T., Safari, S., and Ali, S. R. A. (2018). Characterization of fungi from different ecosystems of tropical peat in Sarawak, Malaysia. Rendiconti Lincei. Scienze Fisiche e Naturali, 29(2): 469-482.

Laser, M., Schulman, D., Allen, S. G., Lichwa, J., Antal, M. J., and Lynd, L. R. (2002). A comparison of liquid hot water and steam pretreatments of sugar cane bagasse for bioconversion to ethanol. Bioresource Technology, 81: 33-44

Levin, L., Herrmann, C., and Papinutti, V. L. (2008). Optimization of lignocellulolytic enzyme production by the white-rot fungus Trametes trogii in solid-state fermentation using response surface methodology. Biochemical Engineering Journal, 39(1): 207-214.

Li, P., Wang, H., Liu, G., Li, X., \& Yao, J. (2011). The effect of carbon source succession on laccase activity in the co-culture process of Ganoderma lucidum and a yeast. Enzyme and microbial technology, 48(1), 16.

Loh, T. C. (2002). Livestock Production and the Feed Industry in Malaysia. Retrieved from http://www.fao.org/docrep/007/y5019e/y5019e0l.htm\#bm21

Lynd, L. R., and Zhang, Y. (2002). Quantitative determination of cellulase concentration as distinct from cell concentration in studies of microbial cellulose utilization: analytical framework and methodological approach. Biotechnology and Bioengineering, 77: 467-475.

Mahlia, T. M. I., Ismail, N., Hossain, N., Silitonga, A. S., and Shamsuddin, A. H. (2019). Palm oil and its wastes as bioenergy sources: a comprehensive review. Environmental Science and Pollution Research: 118.

Malik, N. N., Akhtar, M. W., and Naz, B. A. (1986). Production of cellulase enzymes by Trichoderma harzianum. Poster Abstract. PAEC-KFK. Symp. Workshop on Biotechnology in Agriculture and Energy, March 3-7, 10:

Morand-Fehr, P. (2005). Recent developments in goat nutrition and application: A review. Small Ruminant Research, 60(1): 25-43. 
Moss, A. R., Jouany, J. P., and Newbold, J. (2000). Methane production by ruminants: Its contribution to global warming. Annales Zootechnie, 49: 231-253.

Namoolnoy, P., Phoolphundh, S., and Wongwicharn, A. (2011). Biodegradation of lignin in oil palm fronds by white rot fungi. Kasetsart Journal - Natural Science, 45: 254-259.

Old, K. M., and Schippers, B. (1973). Electron microscopical studies of chlamydospores of Fusarium solani f. cucurbitae formed in natural soil. Soil Biology and Biochemistry, 5(5): 613-620.

Rabelo, S. C., Maciel, R., and Costa, A. C. (2009). Lime pretreatment of sugarcane bagasse for bioethanol production. Applied Biochemistry Biotechnology,153: 139-150.

Revankar, M. S., and Lele, S. S. (2006). Enhanced production of laccase using a new isolate of white rot fungus WR-1. Process Biochemistry, 41(3): 581-588.

Rodríguez, G., Lama, A., Rodríguez, R., Jiménez, A., Guillén, R., and Fernández-Bolaños, J. (2008). Olive stone an attractive source of bioactive and valuable compounds. Bioresource Technology, 99 (13): 52615269 .

Shanmuganvelu, S. (2014). Decision Support System in Livestock Production. Research Inaugural Lecture. Malaysian Agricultural Research and Development Institute (MARDI); Serdang, Malaysia.

Singh, P., Sulaiman, O., Hashim, R., Peng, L. C., \& Singh, R. P. (2013). Evaluating biopulping as an alternative application on oil palm trunk using the white-rot fungus Trametes versicolor. International Biodeterioration \& Biodegradation, 82, 96-103.

Wan Zahari, M., and Farid, M.M., (2011). Oil palm by products as feeds for livestock in Malaysia. In: International Palm Oil Congress (PIPOC 2011) (pp.1-21), 15 -17 Nov 2011, KLCC, Kuala Lumpur, Malaysia.

Wong, D. W. S. (2005). Feruloyl esterase, a key enzyme in biomass degradation. Applied Biochemistry and Biotechnology 133: 87-112

Wulansih, D., Astuti, Komang, G., Wiryawan, Wina, E., Widyastuti, Y., Suharti, S., and Ridwan, R. (2018). Effects of Selected Lactobacillus plantarum as Probiotic on in vitro Ruminal Fermentation and Microbial Population. Pakistan Journal of Nutrition, 17: 131-139.

Zhang, Z., and Zhao, Z. K. (2010). Microwave-assisted conversion of lignocellulosic biomass into furans in ionic liquid. Bioresource Technology, 101(3): 1111-1114.

\section{Figures}


a)

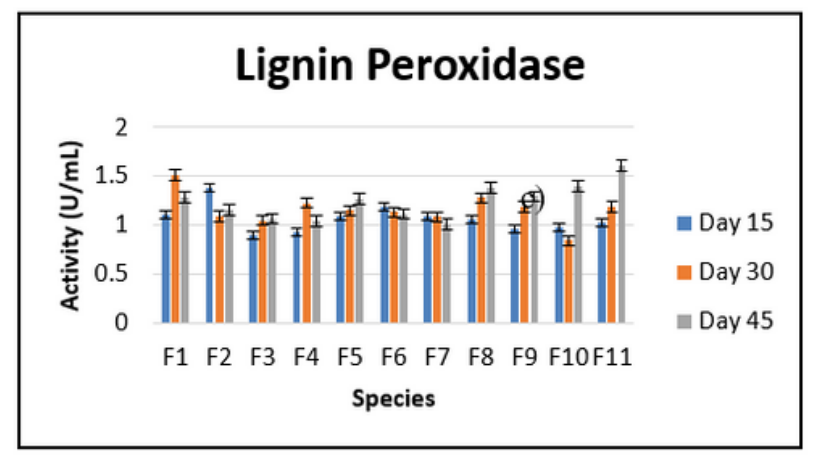

b)

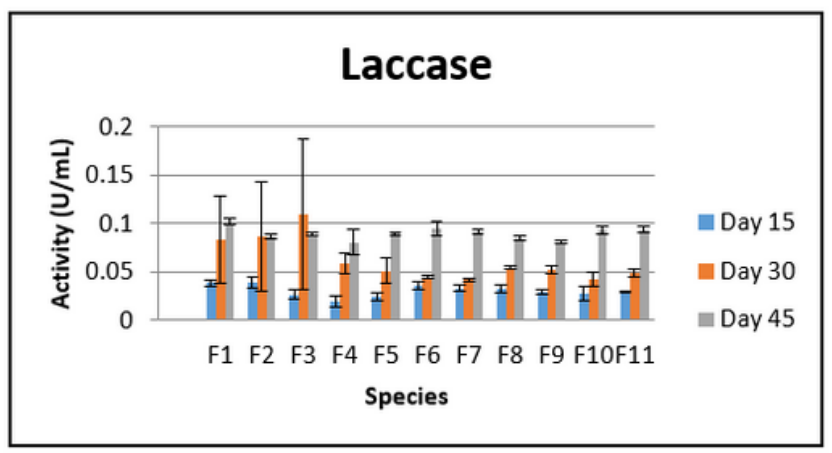

c)

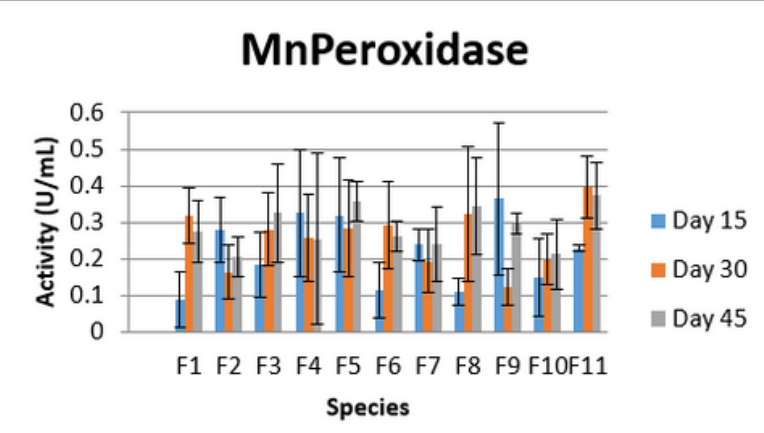

\section{Figure 1}

Activity of Lignolytic Enzymes. Note: Laccase (a), lignin peroxidase (b), and manganese peroxidase (c) of fermented OPF incubated at 15, 30 and 45 days measured in $\mathrm{U} / \mathrm{mL}$

a)

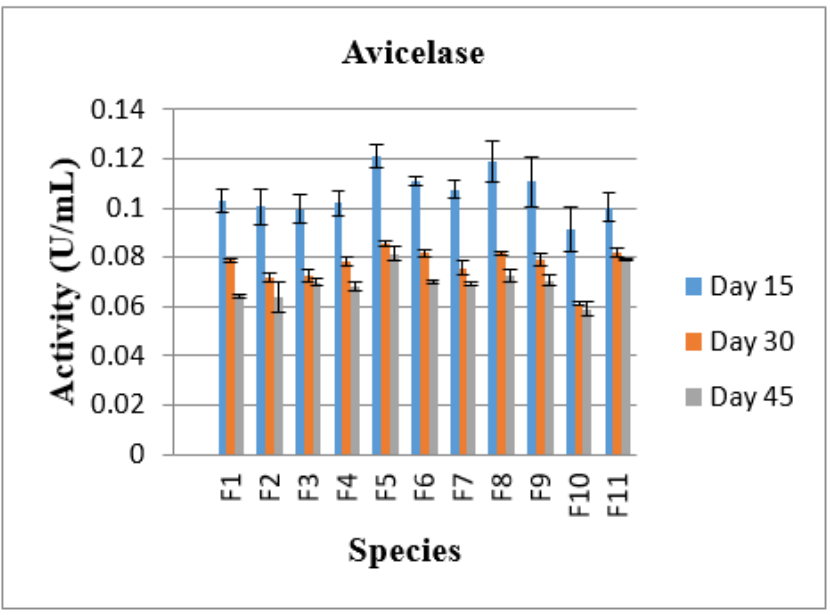

b)

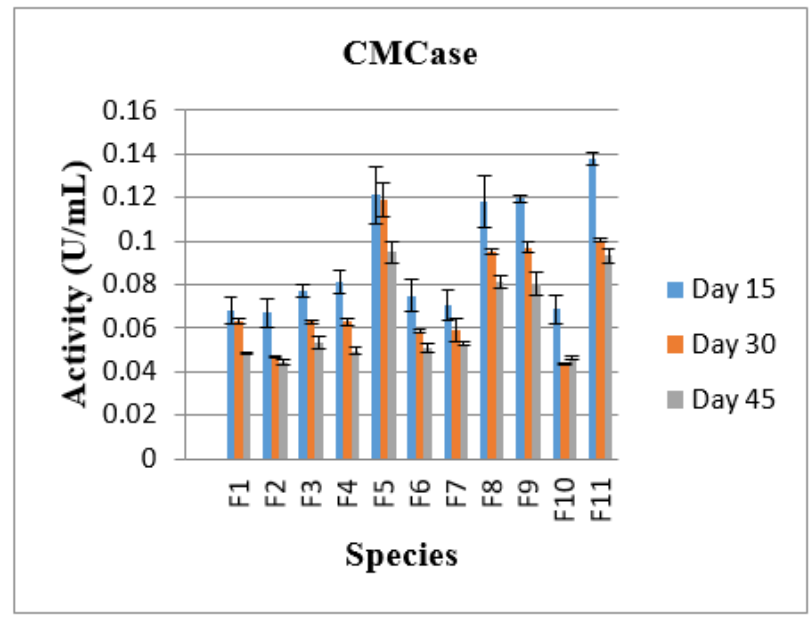

Figure 2

Activity of Cellulolytic Enzymes. Note: Avicelase (a) and carboxymethylcellulase (b) after fermentation with OPF and measured at 15, 30 and 45 days measured in $\mathrm{U} / \mathrm{mL}$. 


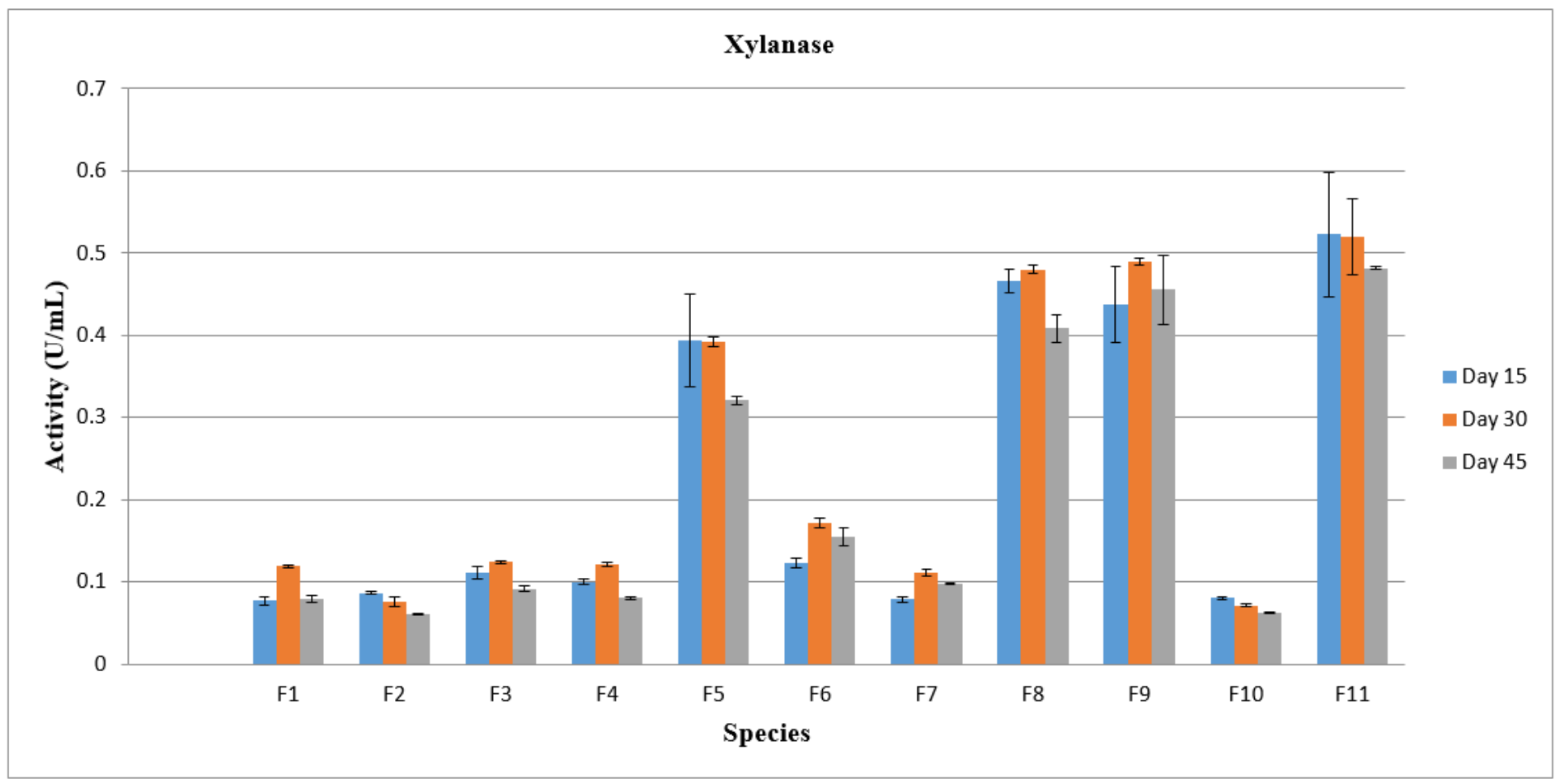

Figure 3

Activity of Hemicellulolytic Enzyme. Note: Xylanase activity after fermentation with OPF and measured at 15,30 and 45 days measured in $\mathrm{U} / \mathrm{mL}$

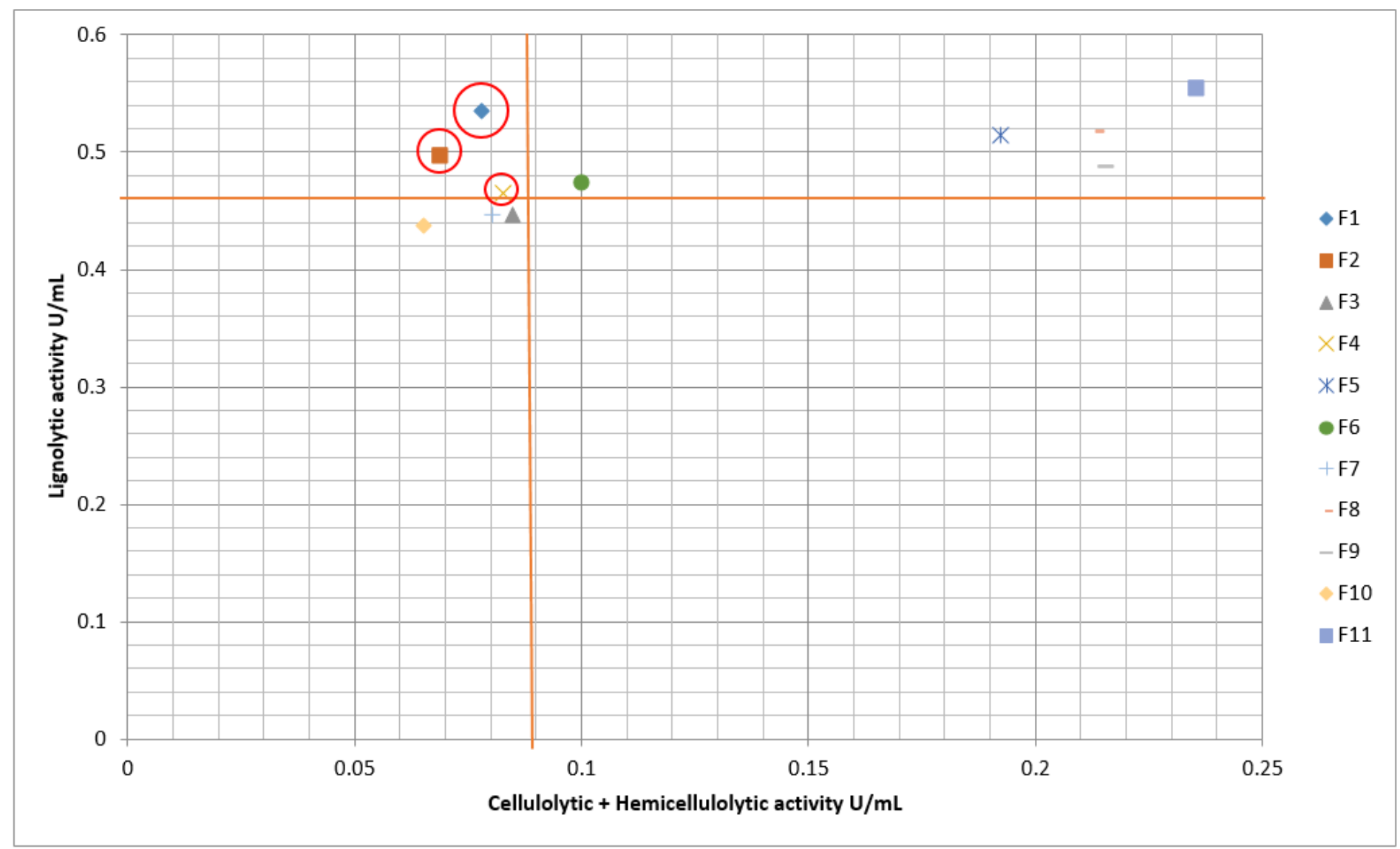




\section{Figure 4}

Scatterplot of Average Lignolytic Enzymes Activity Against Average of Total Cellulolytic and Hemicellulolytic Enzymes Activity.

a)

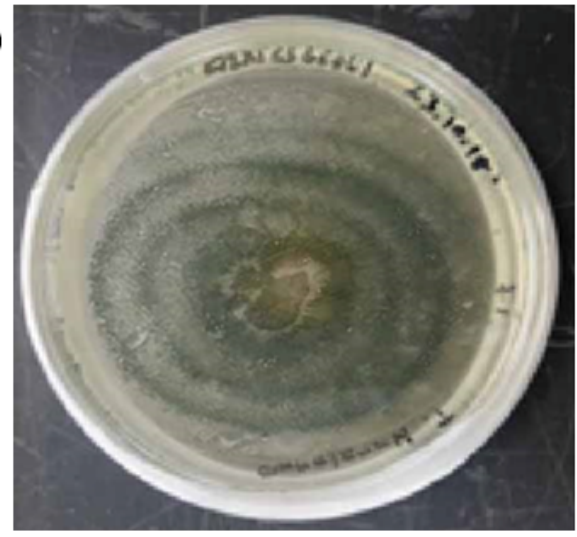

b)

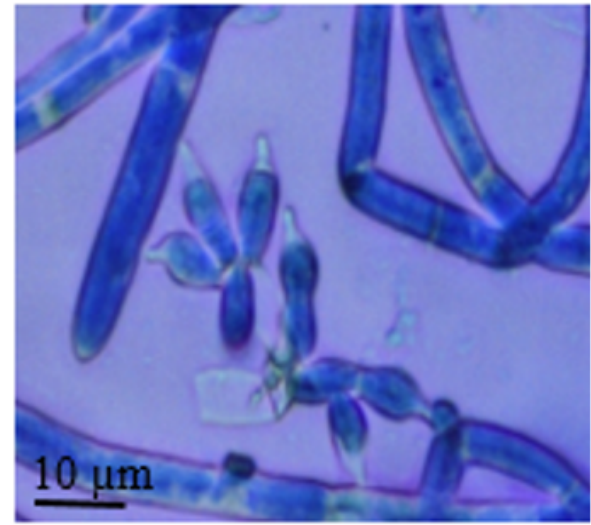

c)

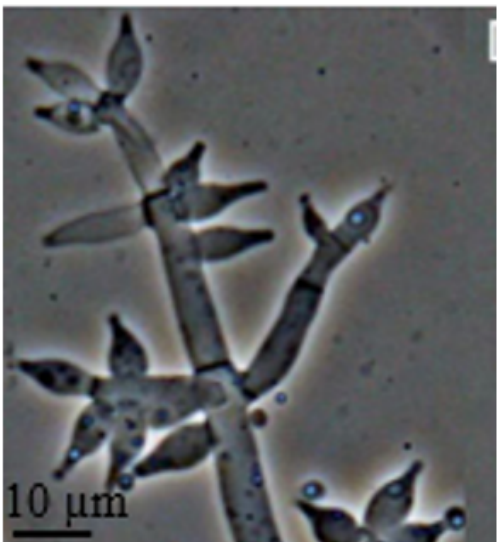

\section{Figure 5}

The Morphological Observation of Fungi F1. Note: a) the morphology of the fungi culture. b) The microscopic observation of the conidia. c) The morphological reference of the fungi conidia (Jang et al., 2018).

a)

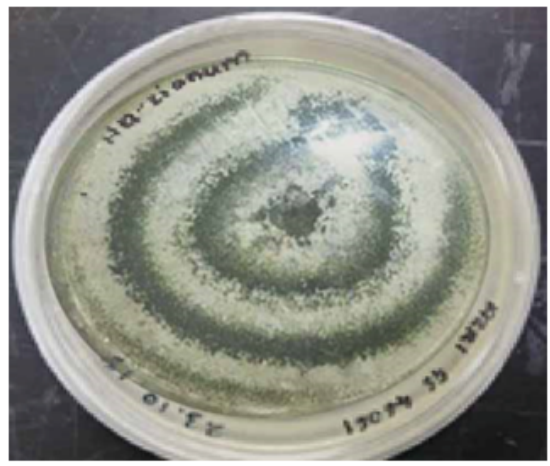

b)

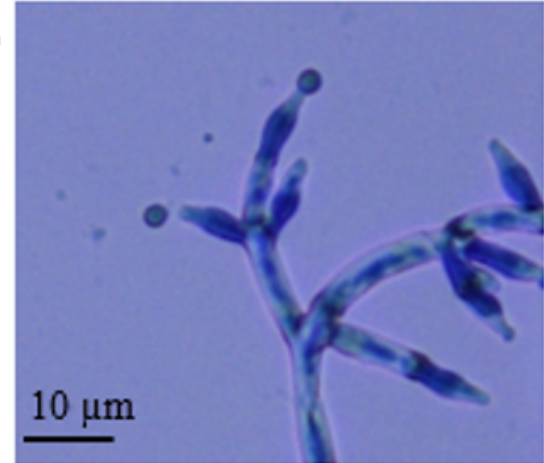

c)

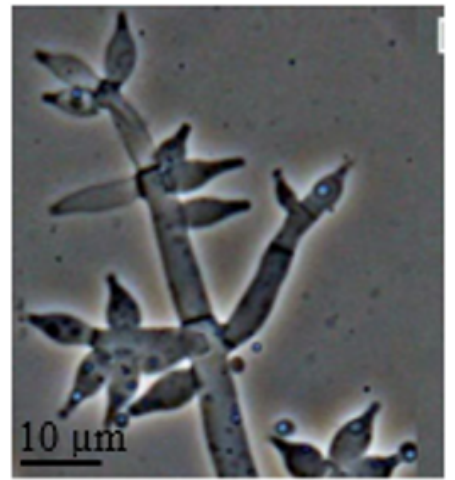

\section{Figure 6}

The Morphological Observation of Fungi F2. Note: a) the morphology of the fungi culture. b) The microscopic observation of the conidia. c) The morphological reference of the fungi conidia (Jang et al., 2018). 
a)

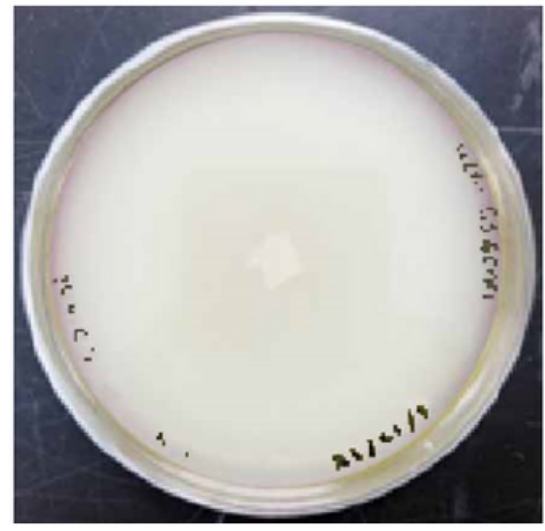

b)

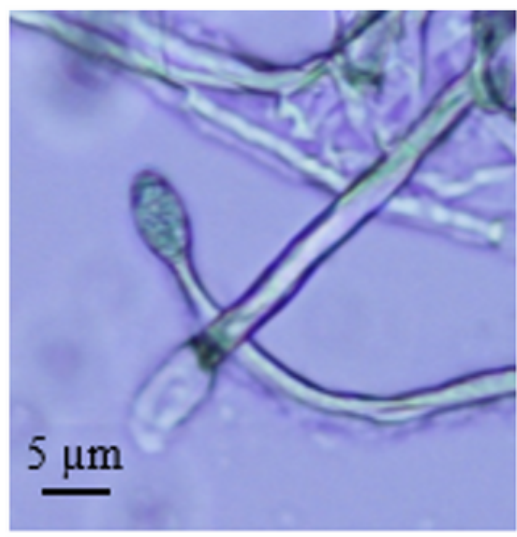

c)

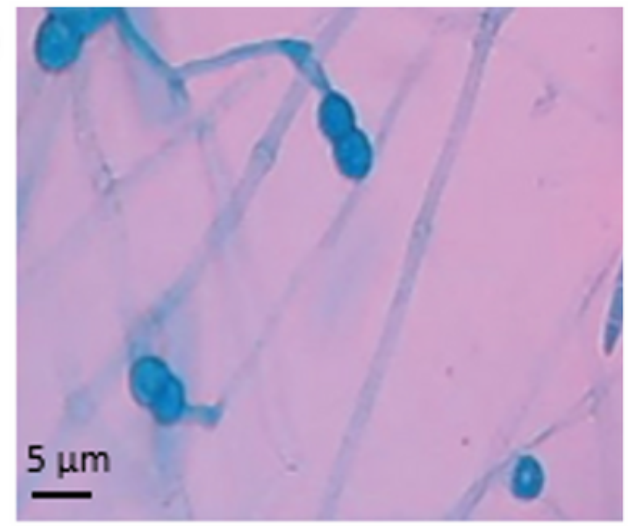

\section{Figure 7}

The Morphological Observation of Fungi F4. Note: a) the morphology of the fungi culture. b) The microscopic observation of the chlamydiaspore. c) The morphological reference of the fungi chlamydiaspore (Kudur et al.,2013).

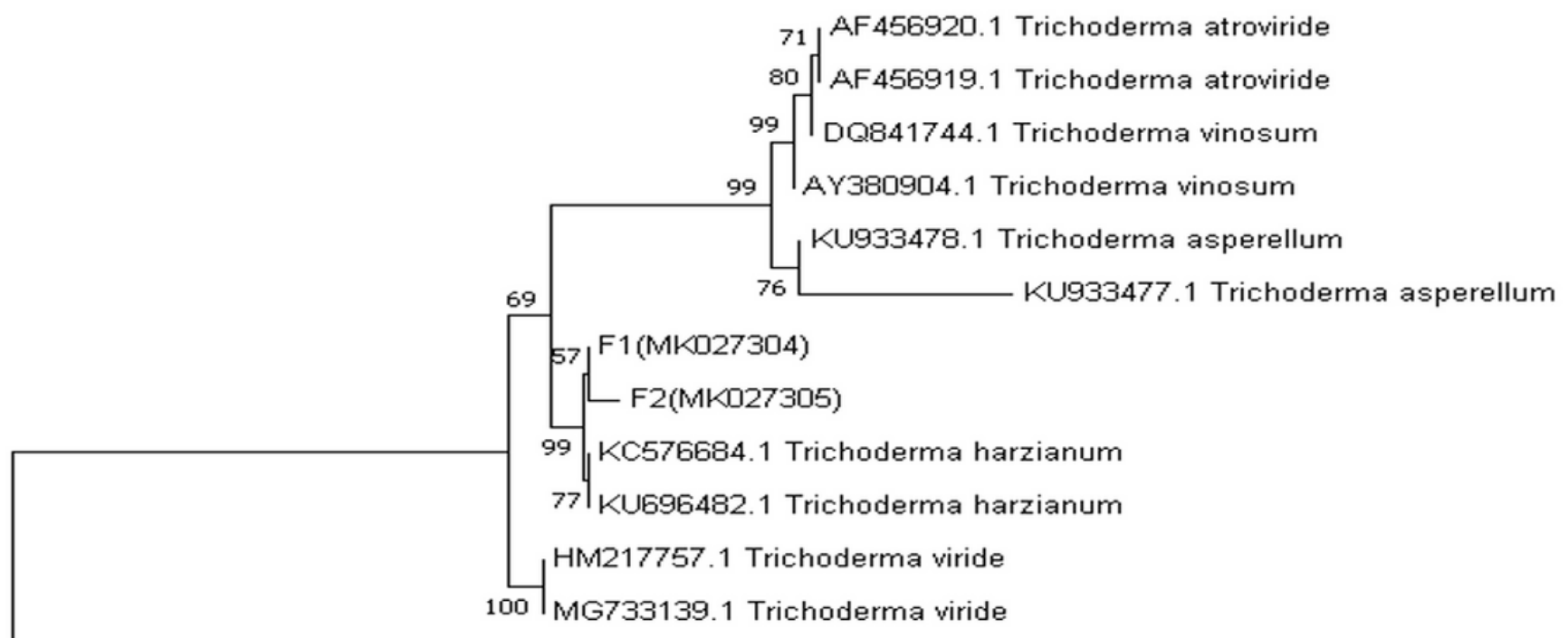

AF160235.1 Sporophagomyces chrysostomus

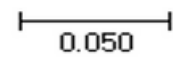

\section{Figure 8}

Phylogenetic Tree for F1 and F2. 


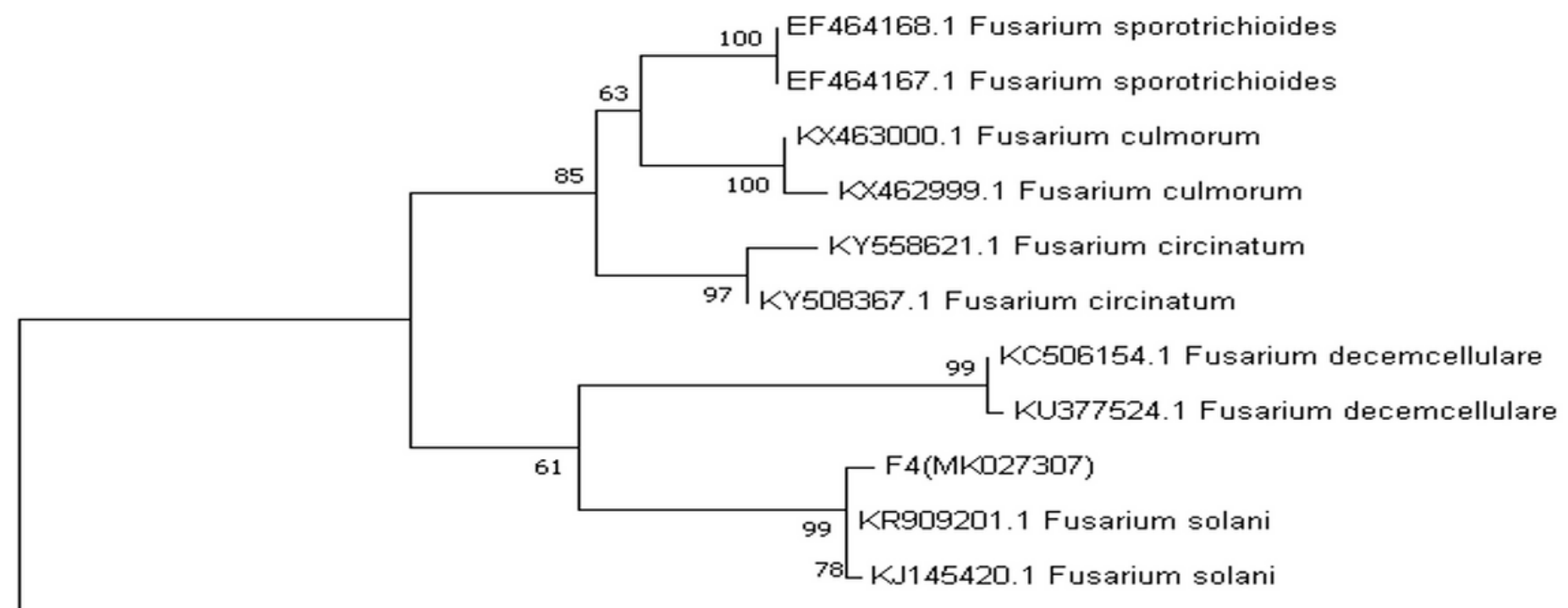

AM993138.1 Xylaria hypoxylon

Figure 9

Phylogenetic Tree for F4

Total Gas Production

18

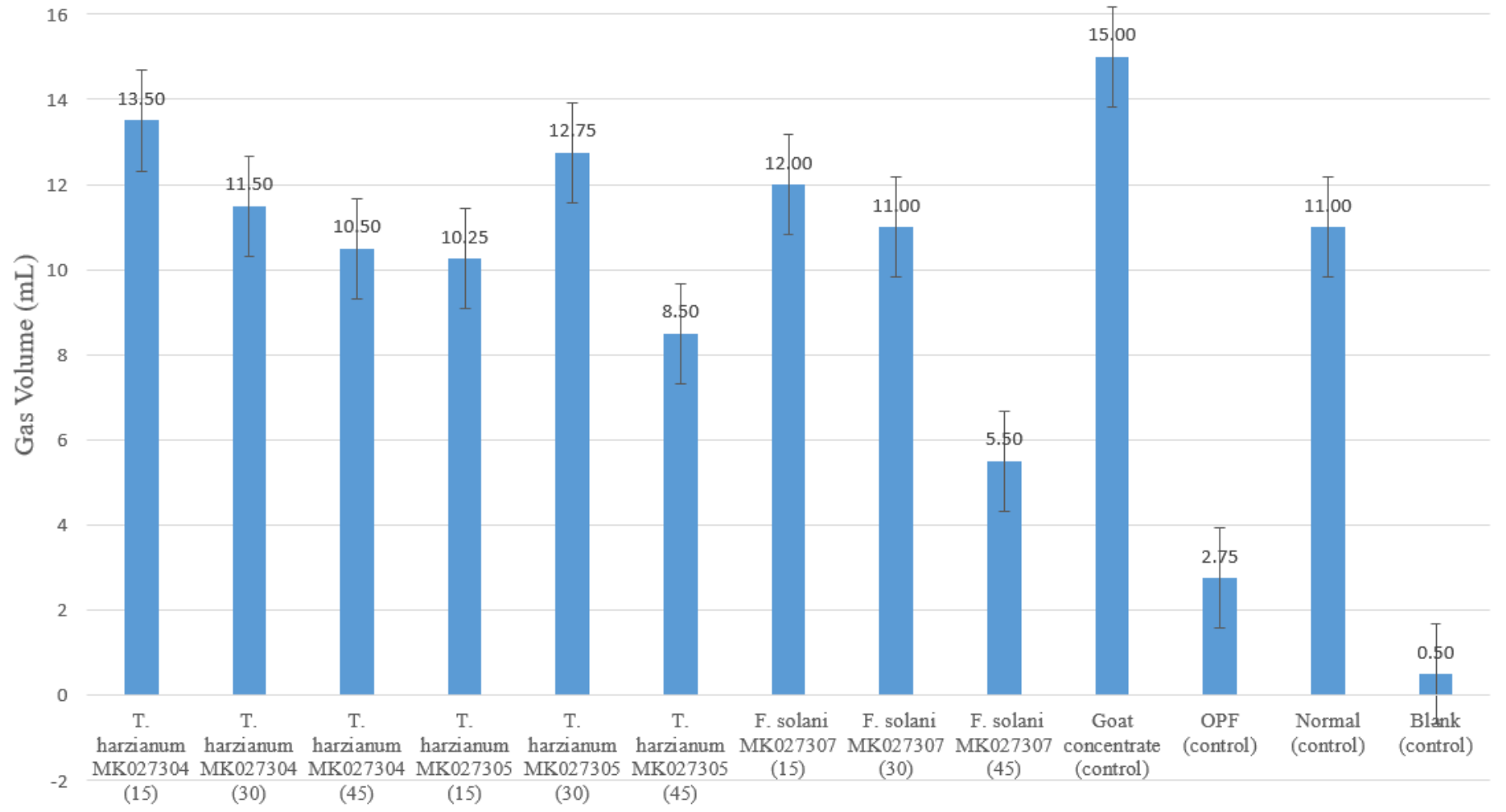


The Average Total Gas Produced in The Syringe Following The 72h Incubation Period.

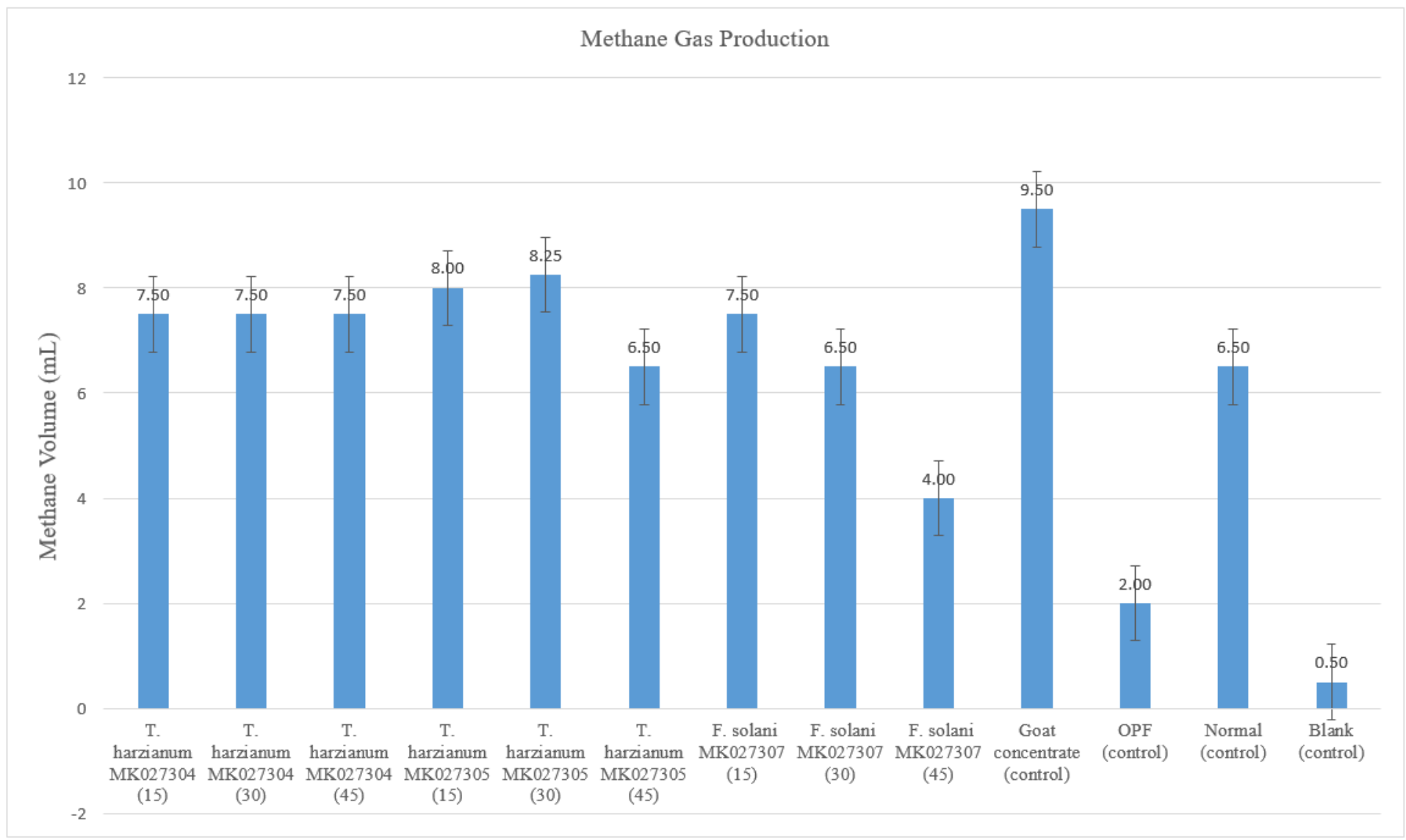

Figure 11

The Average Production of Methane in The Syringe Following 72h of Incubation Period.

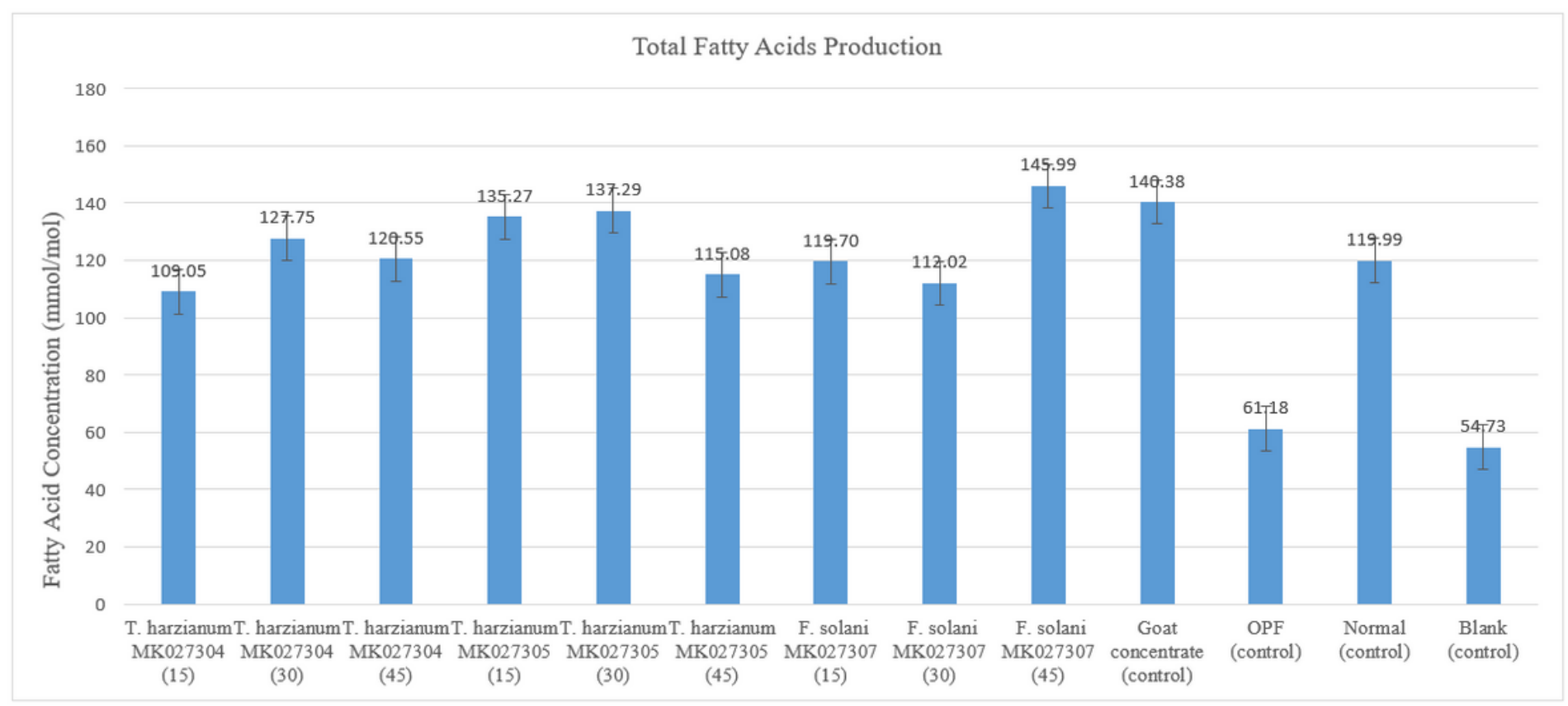

Figure 12 
Total Volatile Fatty Acids Production in The Syringe After $72 \mathrm{~h}$ Incubation.

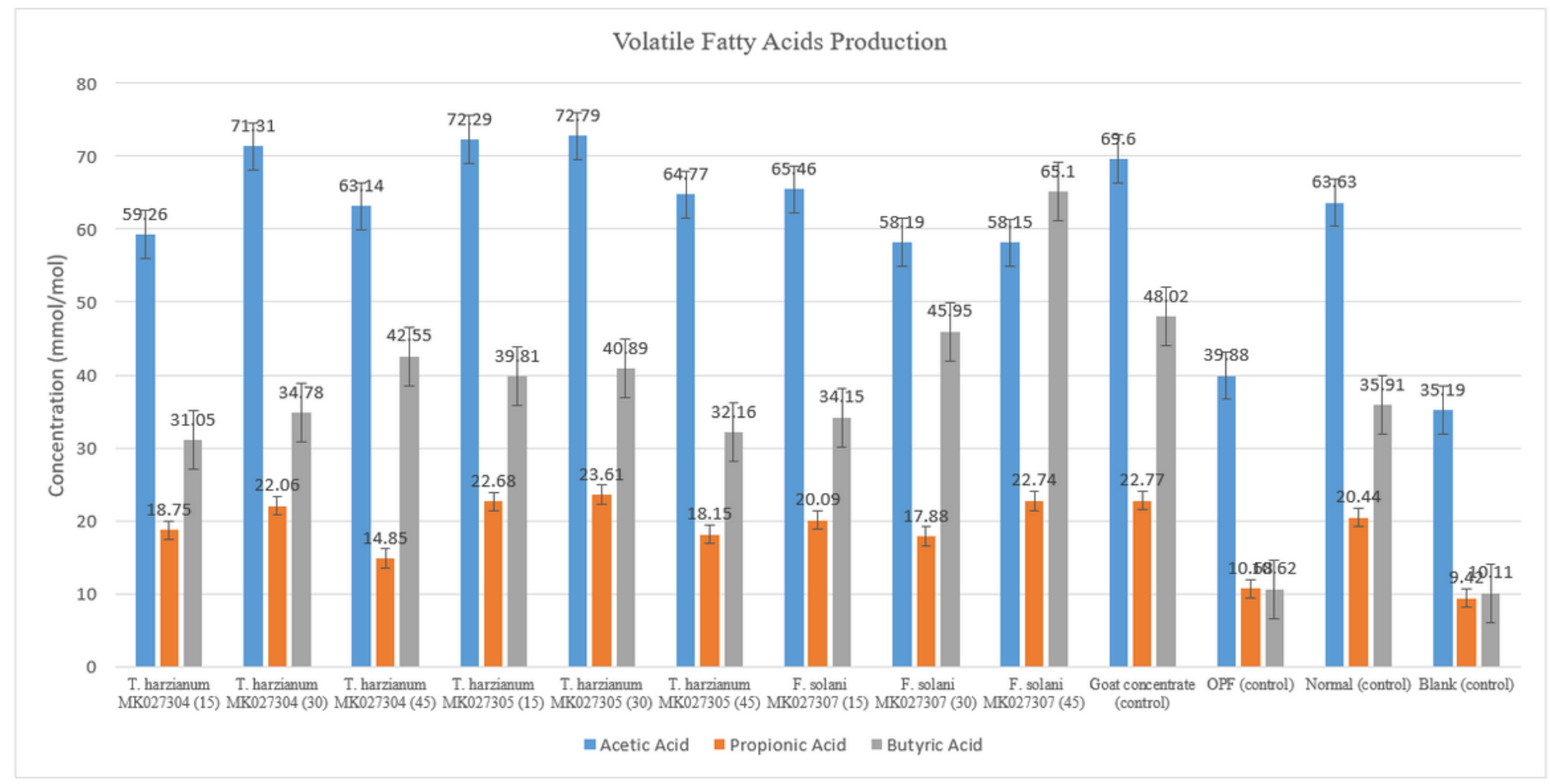

Figure 13

The Production of Acetic Acid, Propionic Acid and Butyric Acid in The Syringe After $72 \mathrm{~h}$ of Incubation Period.

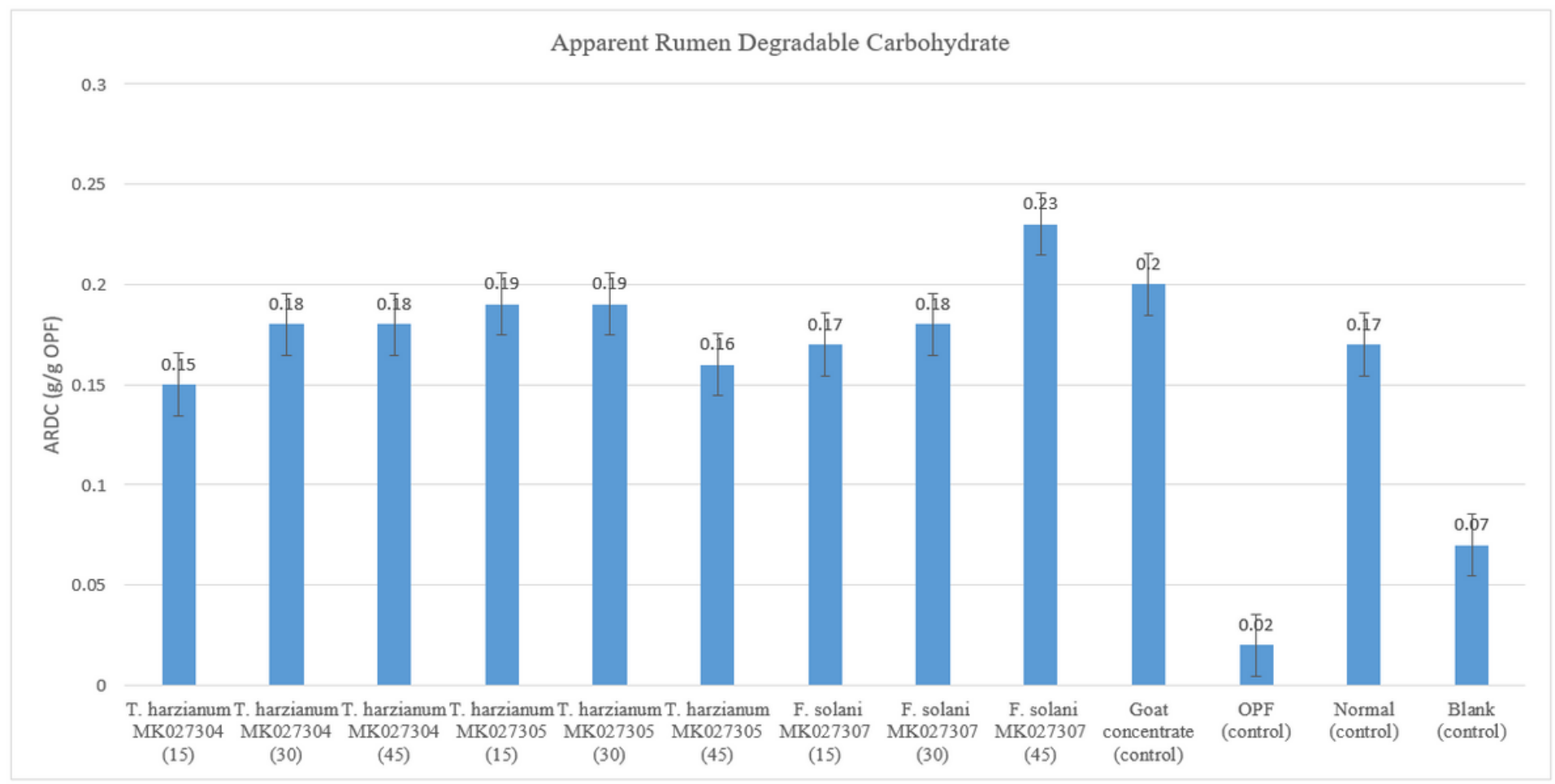

Figure 14 
The Apparent Rumen Degradable Carbohydrate of $\mathrm{g} / \mathrm{g}$ of OPF of Each Syringe Content 